Protective Air Enclosures

in Health Buildings 


\section{Protective Air Enclosures in Health Buildings}

P. A. F. White

O.B.E., B.Sc., F.I.Chem.E., F.I.Mech.E. 
(C) P.A.F. White 1981

Softcover reprint of the hardcover 1st edition 1981 978-0-333-27678-5

All rights reserved. No part of this publication may be reproduced or transmitted, in any form or by any means, without permission.

First published 1981 by

THE MACMILLAN PRESS LTD

London and Basingstoke

Associated companies in Delhi Dublin

Hong Kong Johannesburg Lagos Melbourne

New York Singapore and Tokyo

Typeset in 10/12 Times by

MULTIPLEX techniques ltd, Orpington, Kent

ISBN 978-1-349-05059-8 ISBN 978-1-349-05057-4 (eBook)

DOI 10.1007/978-1-349-05057-4

This book is sold subject to the standard conditions of the Net Book Agreement. 


\section{Contents}

Preface

vii

1. Introduction

Clean Air in Hospitals - The Hospital Environment -

Airborne Infection -

2. Hazardous Aerosols in Health Building Laboratories

Microbiological Laboratories - Chemical Pathology and Histology Laboratories - Radioactive Diagnostic and Therapy Laboratories and Dispensaries - Sources of Aerosols in Laboratories Summary

3. Some Principles related to Protective Air Enclosures

High Efficiency Filters - Mechanism of Filtration - Laminar Air Flow - Clean Air Standards - Air Flow Control

4. Protective Air Enclosures used in Laboratories

Protection of Operator - Protection of the Work Without

Worker Protection - Protection of Both Work and Worker Summary

5. The Design of Air Enclosures for Laboratories

Local Ventilation - Fume Cupboards - Microbiological Safety

Cabinet Class I - Glove Box - Clean Air Cabinets or Clean Air

Work Stations - Vertical Laminar Flow Cabinet or Microbiological Safety Cabinet Class II

6. Ancillaries to Laboratory Enclosures

Washing Sprays and Scrubbers - Automatic Fire Extinguishers Fire Dampers - Flow Setting Damper - Filter Resistance Adjusting Damper - Non-return Damper - Air Flow Indicators - Filters Ducting - Notices and Colour Coding

7. Ventilation Related to Air Enclosures in Laboratories

Number of Room Air Changes - Air Conditioning - Air Supply to Protective Air Enclosures - Pattern of Air Flow in Laboratories - 
Sterile Preparation Rooms - Linkage of Air Enclosures and General Ventilation

8. Fume Extraction and Dispersal

Dilution - Grouping of Air Enclosures - Dispersal from Air Enclosures - Plant Room Construction

9. Operation, Testing and Maintenance

Selection of the Right Unit - General Operation of Protective Air Enclosures - Changing Filters - Disinfection, Sterilisation, Decontamination and Fumigation of Safety Cabinets - Testing and Testing Methods - Maintenance - Identification of Maintenance Hazard Positions - Permit to Work Certification Procedures

10. Operating Rooms

Laminar Flow Systems - Other Protective Air Systems - MRC/ DHSS Sepsis in Operating Rooms Trial - Recirculation of Air to the Operating Room - Filtration Requirement - Relationship of Surrounding Rooms to the Theatre - Engineering Considerations in Operating Suites - Operating, Testing and Maintenance Summary

11. Protective Air Enclosures for Nursing

Laminar Air Flow Rooms - Charnley-Howorth Laminar Flow System with Hoverbed - Protective Nursing Enclosure with Barrier Protection - Comparison of Conventional, Life Island and Laminar Air Flow Rooms - Some Engineering and Operational Problems

12. Other Protective Air Enclosures and Future Developments

Wound Dressing Rooms - Intensive Care Units - Pharmacies Post-Mortem Facilities - Fully Air-Conditioned Hospitals Conservation of Energy - Special Laboratory Air Enclosures Future Developments in Laboratory Enclosures - Engineering Function in Relation to Protective Air Enclosures 


\section{Preface}

The hospital engineering scenario has changed greatly over recent years for there are many areas of concern to the hospital engineer which now approach a high technology level as his involvement with the sophisticated tools of the clinician and laboratory head has increased. There is, however, very little literature in the field of hospital engineering and the hospital engineer has to pick up his knowledge from general texts which often pay little attention to the special problems of health buildings.

In one particular area this book seeks to fill the gap: this is the area concerned with protective air enclosures of many sorts, particularly those occurring in hospital laboratories. It thus covers some general problems of clean atmospheres in hospitals, some specialised clean atmosphere applications as in surgery and nursing, but mainly such protective air enclosures as fume cupboards, safety cabinets and glove boxes used in laboratories.

The book is written chiefly from the angle of the hospital engineer and the consultant/contracting architect/engineer although it touches on the areas of involvement of, and hopefully will be of interest to, pathologists, laboratory scientists, surgeons, clinicians and nurses.

My interest in this area stems firstly from a long involvement in protective gas and air installations in the atomic energy field when I was Head of the Division of Chemical Techology at U.K.A.E.A., Aldermaston, combined with some six years more recently when I have played a small part in the hospital engineering field as an engineering science consultant to the Department of Health and Social Security. I also spent a few years at the Microbiological Research Establishment, Porton. In this total context, this book is a natural sequence to my previous books (Inert Atmospheres in collaboration with S.E. Smith and High Efficiency Filtration in collaboration with Mr Smith and other contributors).

It is therefore a personal attempt to produce a text in which principles concerned with protective atmospheres generally are applied to the hospital field after wide reading and discussion with engineers, scientists, pathologists, hospital laboratory scientists, equipment manufacturers and others.

My direct experience in the hospital environment (a very complicated one, technically) is limited and it must also be made clear that this book in no way represents views or policy of the Department of Health and Social Security in this field. The views and opinions expressed are my own and I am well aware that such diverse views congregate in the hospital scene and that the agreement of many will be countered by the disagreement of some.

To acknowledge all who have helped by discussion or their publications would be impracticable, although I have tried to make clear throughout the book the 
references upon which I have leaned heavily. I must however particularly mention G. Tuson, Assistant Regional Engineer of the Wessex Regional Health Authority, who has given continuous support to my work in this field, and also those who have examined and commented on parts or all of the manuscript, including W. Carson, Leader of the Building Services Research Unit, University of Glasgow; Dr D. Hughes, University of Leeds Radiation Protection Officer; F. Grover, Chief Safety Advisor, Medical Research Council; and G. Harper, Deputy Director, Microbiological Safety Reference Laboratory, Porton. I am also grateful to Mrs B. Diplock for a considerable effort in the typing and clerical field generally. Photographs of equipment have been used widely and I hope I have made the appropriate acknowledgments where these have been provided by industrial firms.

A main aim of the book has been a genuine attempt to increase the safety of activities in health buildings and, without wishing to disarm criticism, it is hoped that critics will appreciate that there are many routes to this objective and all deserve a forum for discussion. 